http://dx.doi.org/10.11646/zoosymposia.15.1.21

http://zoobank.org/urn:lsid:zoobank.org:pub:F2DB1662-B052-4930-BA47-17EE43F059BE

\title{
First observation of the "double-faced X-framed cup ossicle" extracted from a deep sea holothurian in Japan
}

\author{
YUSUKE YAMANA ${ }^{1, *}$, TAKESHI HAYASHIBARA ${ }^{2}$, MASAKI YAMAMOTO $^{3}, \&$ DAVIN H. E. \\ SETIAMARGA $3,4, *$ \\ ${ }^{1}$ Wakayama Prefectural Museum of Natural History, Funo 370-1, Kainan, Wakayama 642-0001, Japan (yamanamako@gmail.com) \\ ${ }^{2}$ Research Center for Subtropical Fisheries, Seikai National Fisheries Research Institute, Fisheries Research and Education Agency, \\ Fukai-Ohta, Ishigaki, Okinawa 907-0451, Japan \\ ${ }^{3}$ Biodiversity Genomics Research Group, Department of Applied Chemistry and Biochemistry, National Institute of Technology, \\ Wakayama College, 77 Noshima, Nada, Gobo City, Wakayama 644-0023, Japan \\ ${ }^{4}$ The University Museum, The University of Tokyo, 7-3-1 Hongo, Bunkyo-ku, Tokyo 133-0033, Japan \\ Corresponding authors: yamanamako@gmail.com(YY: morphological observation),davin@wakayama-nct.ac.jp (DHES: Molecular \\ phylogeny)
}

\begin{abstract}
A New type ossicle form, "double-faced $\mathrm{x}$-framed cup ossicle" is discovered from the undescribed deep sea holothuroid. To give a definite view on the substantial qualities of this ossicle, a SEM observation on the ossicles and a DNA barcoding analysis are conducted. Although the most internal and external morphologies of the present species agree well with the characteristics of the family Cucumariidae Ludwig, 1894, the ossicles morphologies mostly does not agree with the congeners of Cucumariidae. On the other hand, our molecular study indicates a possibility that the specimens are not cucumariids, but belong to a sister group of Cucumariidae. In our present observation, some of the peri-oral ossicles show a very similar property with the small $\mathrm{x}$-framed cup-shaped structures (which sometimes occurs in cucumariids). Therefore, the double-faced $x$-framed cup ossicle probably could be considered as the results of derivation from the x-body: in which four extra-arms developed on the bottom face of a cup ossicle, and finally these arms equipped with an extra-rim.
\end{abstract}

Key words: Cucumariidae, Dendrochirotida, DNA barcoding, molecular phylogeny

\section{Introduction}

In the studies on holothurians, highly variegated forms of ossicles have been reported. Although many species show specific ossicle structures, the various shapes of ossicles are considered as the results of derivation from the fundamental forms of the following basic types: plate; table; button; scale; rosette; cup; wheel; sigmoid hook; anchor; granule; needle; and rod. However recently, one taxonomically undescribed species was discovered from the deep water of Japan, which possesses a peculiar ossicle shape different from all the fundamental forms previously reported. Here, we report the first observation of a double-faced $x$-framed cup ossicle from an undescribed deep sea holothuroid, collected from the Satsuma Peninsula in Kagoshima, Japan. SEM observation on the ossicles was carried out to give a definite view on the substantial qualities of this ossicle. We also conducted a DNA barcoding analysis using the mitochondrial gene COI and the nuclear Histone $\mathrm{H} 3$ gene to examine the phylogenetic position of this species, in order to provide a systematics background for the explanation of this ossicle. 


\section{Materials and Methods}

Eleven specimens were collected from off the Satsuma Peninsula (Kagoshima) at $200 \mathrm{~m}$ depth by R/V Kaiyomaru using ROV (Kowa Co.Ltd). The specimens were then fixed and preserved in $80 \%$ ethanol. All specimens and the permanent slides of the ossicles are deposited in the Invertebrate Collection (INV) of the Wakayama Prefectural Museum of Natural History (WMNH), in Kainan, Wakayama, Japan.

For SEM study, the ossicles were extracted from several parts of a single specimen. First, tissue samples were dissolved in sodium hypochlorite $(\mathrm{NaClO}, 5 \%)$. Afterward, the samples were rinsed in deionized water, and then dehydrated in $99 \%$ ethanol. Dehydrated samples were then mounted on aluminium stubs using conductive tapes (Nisshin NEM Tape), dried at room temperature, and finally observed using a scanning electron microscope (Nippondenshi JEOL JSM-6480LV). SEM materials were also deposited in WMNH.

We also observed the outer body-wall ossicles of Hemiocnus tegulatus (Augustin, 1908, also see Yamana \& Kohtsuka, 2018) (specimen registration: WMNH-INV-2015-307), as an example of the normal single-faced $\mathrm{x}$-framed cups (x-bodies) of the congeners of Cucumariidae.

For DNA analysis, a piece of the muscle tissue (ca. $25 \mathrm{mg}$ ) were extracted from three of the vouchered, EtOH-fixed samples (WMNH-INV-2018-7, 8, and 9). Fragments of the mitochondrial COI gene and the nuclear Histone $\mathrm{H} 3$ gene were amplified and then sequenced. PCR reactions follow standard protocols, and sequencing was outsourced. PCR primers used for COI were COIceF and COIceR (Hoareau and Boissin 2010); and for Histone $\mathrm{H} 3$ were $\mathrm{H} 3 \mathrm{aF}$ and $\mathrm{H} 3 \mathrm{aR}$ (Colgan et al. 1998) we were successful in obtaining COI and Histone $\mathrm{H} 3$ sequences of all three individuals. Obtained sequences were visualized in MESQUITE ver. 3.5 (Maddison and Maddison 2018) for editing prior and post-alignment. Sequence alignment were conducted using the online version of MAFFT ver. 7 (Katoh et al. 2017). After alignment and editing, the two gene sequences were concatenated and used in subsequent phylogenetic analyses. Sequences for selected taxa from Miller et al. (2017) were also data-mined and included in the analyses (Table 1). Maximum Likelihood phylogenetic analyses were conducted using the program RAxML-GUI ver 1.5 beta (Silvestro and Michalak 2012) under the GTR+GAMMA model, and Neighbor Joining analyses were conducted using MEGA 7 (Kumar et al. 2016) under the Maximum Composite Likelihood substitution model, GTR nucleotide substitution rate, and 30\% cutoff for each site. Both analyses were done with 1000 bootstrap replications to assess the robustness of each node. To minimize the effect of homoplasy caused by oversaturation, we conducted phylogenetic analyses with the third codon of the mitochondrial COI gene excluded.

TABLE 1. List of selected OTU from Miller et al. (2017) acquired from Genbank.

\begin{tabular}{clll}
\hline Order & \multicolumn{1}{c}{ Species } & COI & H3 \\
\hline & Abyssocucumis abyssorum & KX874335 & KX874442 \\
& Afrocucumis africana & KX874348 & KX874451 \\
& Aslia pygmaea & KX874339 & KX874450 \\
& Crucella scotiae 1 & KX874366 & KX874433 \\
& Crucella scotiae 2 & KX874367 & KX874434 \\
& Echinocucumis cf. hispida & KX874395 & KX874437 \\
& Echinocucumis hispida & KX874438 \\
& Euthyonidiella huwi & KX874371 & KX874448 \\
& Heterothyone alba & KX874390 & KX874444 \\
& Lissothuria nutriens & KX874341 & KX874443 \\
& Massinium magnum & KX874351 & KX874467 \\
& Pachythyone rubra & KX874387 & KX874446 \\
& Paracucumis turricata & KX874368 & KX874439 \\
& Pentactella leonina & KX874369 & KX874440 \\
& Pentactella sp. & KX874372 & KX874441 \\
\hline
\end{tabular}


TABLE 1. (Continued)

\begin{tabular}{|c|c|c|c|}
\hline Order & Species & $\mathrm{COI}$ & H3 \\
\hline \multirow{7}{*}{ Dendrochirotida } & Phyrella mookiei & KX874346 & KX874477 \\
\hline & Placothuria squamata & KX874391 & KX874445 \\
\hline & Psolidium dorsipes & KX874350 & KX874435 \\
\hline & Psolidium whittakeri & KX874349 & KX874432 \\
\hline & Sclerodactyla briareus & KX874342 & KX874447 \\
\hline & Thyonella gemmata & KX874340 & KX874449 \\
\hline & Ypsilothuria cf. bitentaculata & KX874370 & KX874436 \\
\hline \multirow{7}{*}{ Synallactida } & Deima validum & KX874364 & KX874426 \\
\hline & Orphnurgus glaber & KX874361 & KX874428 \\
\hline & Oneirophanta setigera & KX874363 & KX874427 \\
\hline & Paelopatides sp. 2 & KX874355 & KX874419 \\
\hline & Stichopus chloronotus & KX874352 & KX874424 \\
\hline & Synallactes sp. & KX874365 & KX874420 \\
\hline & Thelenota anax & KX874375 & KX87442 \\
\hline \multirow{3}{*}{ Molpadida } & Acaudina molpadioides & KX874336 & KX874455 \\
\hline & Heteromolpadia tridens & KX874362 & KX874431 \\
\hline & Paracaudina chilensis & KX874343 & KX874414 \\
\hline \multirow{3}{*}{ Persiculida } & Gephyrothuria alcocki & KX874377 & KX874406 \\
\hline & Paroriza prouhoi & KX874378 & KX874405 \\
\hline & Pseudostichopus sp. 2 & KX874389 & KX874454 \\
\hline \multirow{3}{*}{ Holothuriida } & Actinopyga varians & KX874345 & KX874409 \\
\hline & Holothuria hilla & KX874337 & KX874407 \\
\hline & Mesothuria oktaknemus & KX874394 & KX874429 \\
\hline \multirow{4}{*}{ Elasipodida } & Amperima robusta & KX874381 & KX874457 \\
\hline & Enypniastes eximia & KX874383 & KX874465 \\
\hline & Pannychia cf. moseleyi & KX874379 & KX874464 \\
\hline & Protelpidia murrayi & KX874382 & KX874456 \\
\hline \multirow{4}{*}{ Apodida } & Chiridota laevis & KX874399 & KX874473 \\
\hline & Chiridota rigida & KX874401 & KX874469 \\
\hline & Euapta tahitiensis & KX874402 & KX874475 \\
\hline & Paradota $s p$ & KX874400 & KX874470 \\
\hline \multirow{2}{*}{ Outgroups } & Patiria miniata & KX874393 & KX874430 \\
\hline & Hemicentrotus pulcherrimus & JQ742947.1 & LC275143.1 \\
\hline
\end{tabular}

\section{Results}

Morphological observation

For familial assignments, body internal and external morphology were checked based on eleven specimens. The morphological characterization result is as follows.

Body medium, approximately $20-80 \mathrm{~mm}$ in length and $6-25 \mathrm{~mm}$ in width. Body color yellow in living (Fig. 1a), white in preservation (Fig. 1b). The body was cylindrical, the skin soft, with five oral valves present. 
Polian vesicle and stone canal single, with ten dendritic tentacles arranged in a single circle. Calcareous ring was short, stout, with no posterior prolongations. The medioventral radial element and two inter-radial elements were not fused. Ten anal papillae and five anal teeth in radii were present. The tube feets were distributed in three ventral radii, retractile, and lacking in the dorsal side. The gonad was situated in the anterior side of body in two clumps, one on each side of the dorsal mesentery, with most tubules branched.

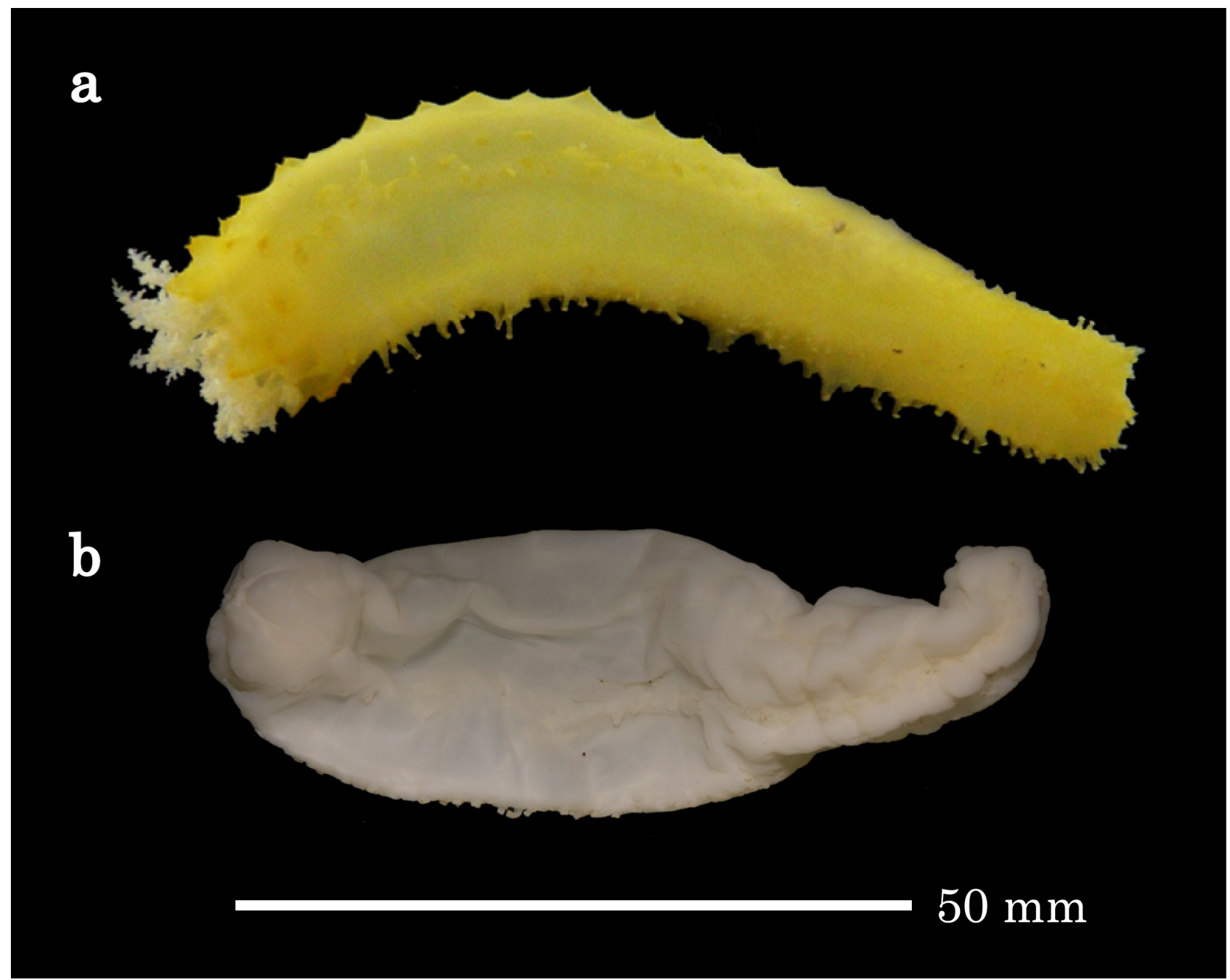

FIGURE 1. Lateral views of taxonomically unsolved species collected from deep sea Japan. (a) Live specimen, (b) preserved specimen (the same individual of Fig. 1a).

\section{Ossicle morphology}

Body wall ossicles were mostly peculiar shape: small, $x$-framed, and dice-shaped, namely "double-faced $\mathrm{x}$ framed cup ossicle" (Fig. 2a), and rarely show dendriformed rods in the inner body-wall (Fig. 2b). However, interestingly, the body ossicles completely lack buttons, plates, $x$-bodies, cups and/or baskets. The tube feet ossicles also mostly double-faced $\mathrm{x}$-framed cup ossicle, with small numbers of terminal supporting plates (Fig. 2c) and usual endplate. The peri-oral ossicles were $x$-framed cup-shaped structures (Fig. 2d), with large rods (Fig. 2e) and double-faced $\mathrm{x}$-framed cup ossicle.

Front views of the rims of body wall double-faced $x$-framed cup ossicles are square, centrally with $x$ frame, marginally with spinous processes (Fig. 2, a1-a6). There are more numbers of processes on the upside rim than on the downside rim. Side views are also square, because of four pillars that united the both rims together (Fig. 2, a7-a11). However, some ossicles are partially or completely lacking of rims of upside and/or downside (Fig. 2, a6 and a12). On the other hand, most of the peri-oral ossicles are completely lacking of downside rim (Fig. 2d), resulted in the normal x-framed cup ossicles possessing central $x$-frame and upside rim that partially reduced frequently. 

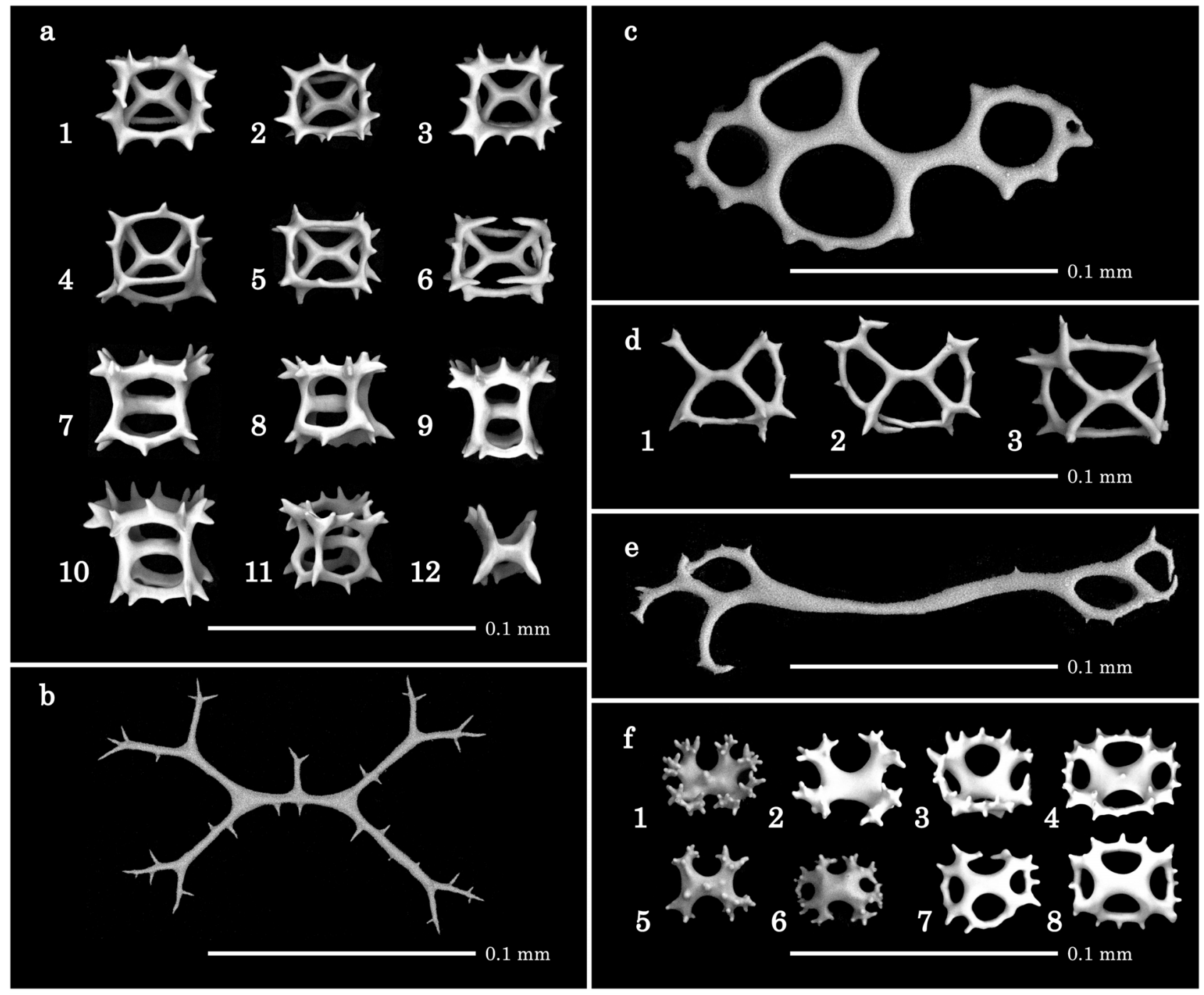

FIGURE 2. (a-e) Ossicles of taxonomically unsolved species collected from deep sea Japan, and (f) the outer body-wall ossicles of Hemiocnus tegulatus (Augustin, 1908). (a) double-faced x-framed cup ossicle from outer body-wall, a1-a3: top views, a4-a6: bottom views, a7-a12: side views, (b) dendriformed rod from inner body-wall, (c) supporting plate from tube feet tip, (d) x-framed cup-shaped structures from peri-oral skin, d1-d3: bottom views, and (e) large rod from peri-oral skin. (f) Outer body-wall ossicles of Hemiocnus tegulatus (Augustin, 1908) (specimen registration: WMNH-INV-2015-307), as the examples of the single-faced $\mathrm{x}$-framed cups (x-bodies), f1-f4: top views, f5-f8: bottom views.

\section{Molecular phylogeny}

In this study, we sequenced portions of the mitochondrial gene COI and the nuclear gene Histone H3, and conducted phylogenetic analyses together with selected holothuroid sequences included in Miller et al. (2017). From eleven samples morphologically examined, we selected three individuals to be sequenced (WMNH-INV-2018-7, 8, and 9, Genbank accession numbers are LC425500, LC425501, and LC425502 for COI, and LC425503, LC425504, and LC425505 for H3, respectively). We obtained 659 bp (and 439 bp after the exclusion of the $3^{\text {rd }}$ codon) of COI and $334 \mathrm{bp}$ of Histone $\mathrm{H} 3$ post-alignment, which were then used in the subsequent analyses. Although bootstrap supports were low (especially for the nodes of higher phylogeny and/or for datasets with the third codon of COI included), the topology of our phylogenetic trees are congruent with that of Miller et al. (2017) (Fig. 3). Our phylogenetic analyses have repeatedly placed the undescribed species inside Dendrochirotida. BLAST results using sequences of the specimens as queries, also support this result (Table 2). Phylogenetic trees with the third codon of the COI gene included are also provided as supplementary results (Fig. 4). 
TABLE 2. BLAST results of the genes amplified from specimens used in this study.

\begin{tabular}{|c|c|c|c|c|c|}
\hline Gene & Specimen & BLAST result & E-value & Identity & $\begin{array}{l}\text { Genbank } \\
\text { ID }\end{array}$ \\
\hline \multirow{2}{*}{$\mathrm{H} 3$} & \multirow{2}{*}{$\begin{array}{l}\text { INV- } \\
2018-7\end{array}$} & $\begin{array}{l}\text { Psolus phantapus isolate D } \\
\text { histone } \mathrm{H} 3(\mathrm{H} 3) \text { gene, partial cds }\end{array}$ & $3.00 \mathrm{E}-151$ & $\begin{array}{l}336 / 356 \\
(94)\end{array}$ & $\begin{array}{c}\mathrm{KP} \\
113611.1\end{array}$ \\
\hline & & $\begin{array}{l}\text { Echinocucumis cf. hispida AM-2017 } \\
\text { histone H3 (H3) gene, partial cds }\end{array}$ & $4.00 \mathrm{E}-150$ & $\begin{array}{l}321 / 335 \\
(96)\end{array}$ & $\begin{array}{c}\mathrm{KX} \\
874437.1\end{array}$ \\
\hline \multirow{2}{*}{$\mathrm{H} 3$} & \multirow{2}{*}{$\begin{array}{l}\text { INV- } \\
2018-8\end{array}$} & $\begin{array}{l}\text { Psolus phantapus isolate D } \\
\text { histone } \mathrm{H} 3(\mathrm{H} 3) \text { gene, partial cds }\end{array}$ & $7.00 \mathrm{E}-153$ & $337 / 356(95)$ & $\begin{array}{c}\text { KP } \\
113611.1\end{array}$ \\
\hline & & $\begin{array}{l}\text { Echinocucumis cf. hispida AM-2017 } \\
\text { histone H3 (H3) gene, partial cds }\end{array}$ & $4.00 \mathrm{E}-150$ & $\begin{array}{l}321 / 335 \\
(96)\end{array}$ & $\begin{array}{c}\mathrm{KX} \\
874437.1\end{array}$ \\
\hline \multirow{2}{*}{$\mathrm{H} 3$} & \multirow{2}{*}{$\begin{array}{l}\text { INV- } \\
2018-9\end{array}$} & $\begin{array}{l}\text { Psolus phantapus isolate D } \\
\text { histone } \mathrm{H} 3(\mathrm{H} 3) \text { gene, partial cds }\end{array}$ & $3.00 \mathrm{E}-151$ & $336 / 356(94)$ & $\begin{array}{c}\mathrm{KP} \\
113611.1\end{array}$ \\
\hline & & $\begin{array}{l}\text { Echinocucumis cf. hispida AM-2017 } \\
\text { histone H3 (H3) gene, partial cds }\end{array}$ & $4.00 \mathrm{E}-150$ & $\begin{array}{l}321 / 335 \\
\quad(96)\end{array}$ & $\begin{array}{c}\text { KX } \\
874437.1\end{array}$ \\
\hline \multirow{2}{*}{$\mathrm{COI}$} & \multirow{2}{*}{$\begin{array}{l}\text { INV- } \\
2018-7\end{array}$} & $\begin{array}{l}\text { Afrocucumis africana voucher SIO: BIC: E6844 } \\
\text { cytochrome c oxidase subunit I (COI) gene, partial } \\
\text { cds; } \\
\text { mitochondrial }\end{array}$ & $1.00 \mathrm{E}-126$ & $396 / 468(85)$ & $\begin{array}{c}\mathrm{KX} \\
874348.1\end{array}$ \\
\hline & & $\begin{array}{l}\text { Cucumaria miniata voucher BIOUG: BAM00037 } \\
\text { cytochrome oxidase subunit } 1 \text { (COI) gene, partial } \\
\text { cds; } \\
\text { mitochondrial }\end{array}$ & $3.00 \mathrm{E}-123$ & $\begin{array}{l}381 / 449 \\
(85)\end{array}$ & $\begin{array}{c}\text { HM } \\
542157.1\end{array}$ \\
\hline \multirow[b]{2}{*}{$\mathrm{COI}$} & \multirow[b]{2}{*}{$\begin{array}{l}\text { INV- } \\
2018-8\end{array}$} & $\begin{array}{l}\text { Cucumaria miniata voucher BIOUG: BAM00037 } \\
\text { cytochrome oxidase subunit } 1 \text { (COI) gene, partial } \\
\text { cds; } \\
\text { mitochondrial }\end{array}$ & 0 & $\begin{array}{l}570 / 676 \\
(84)\end{array}$ & $\begin{array}{c}\text { HM } \\
542157.1\end{array}$ \\
\hline & & $\begin{array}{l}\text { Psolus chitonoides cytochrome oxidase } 1 \text { (CO1) } \\
\text { gene, } \\
\text { partial cds, and large subunit rRNA gene, partial } \\
\text { sequence, } \\
\text { mitochondrial genes encoding mitochondrial } \\
\text { products }\end{array}$ & 0 & $\begin{array}{c}562 / 664 \\
(85)\end{array}$ & $\begin{array}{c}\mathrm{U} \\
32220.1\end{array}$ \\
\hline \multirow{2}{*}{$\mathrm{COI}$} & \multirow{2}{*}{$\begin{array}{c}\text { INV- } \\
2018-9\end{array}$} & $\begin{array}{l}\text { Psolus chitonoides voucher BIOUG: BAM00144 } \\
\text { cytochrome oxidase subunit } 1 \text { (COI) gene, partial } \\
\text { cds; } \\
\text { mitochondrial }\end{array}$ & $3.00 \mathrm{E}-177$ & $\begin{array}{c}539 / 637 \\
(85)\end{array}$ & $\begin{array}{c}\text { HM } \\
542342.1\end{array}$ \\
\hline & & $\begin{array}{l}\text { Psolus chitonoides voucher BIOUG: BAM00038 } \\
\text { cytochrome oxidase subunit } 1 \text { (COI) gene, partial } \\
\text { cds; } \\
\text { mitochondrial }\end{array}$ & $1.00 \mathrm{E}-175$ & $\begin{array}{c}538 / 637 \\
(84)\end{array}$ & $\begin{array}{c}\text { НM } \\
542341.1\end{array}$ \\
\hline
\end{tabular}



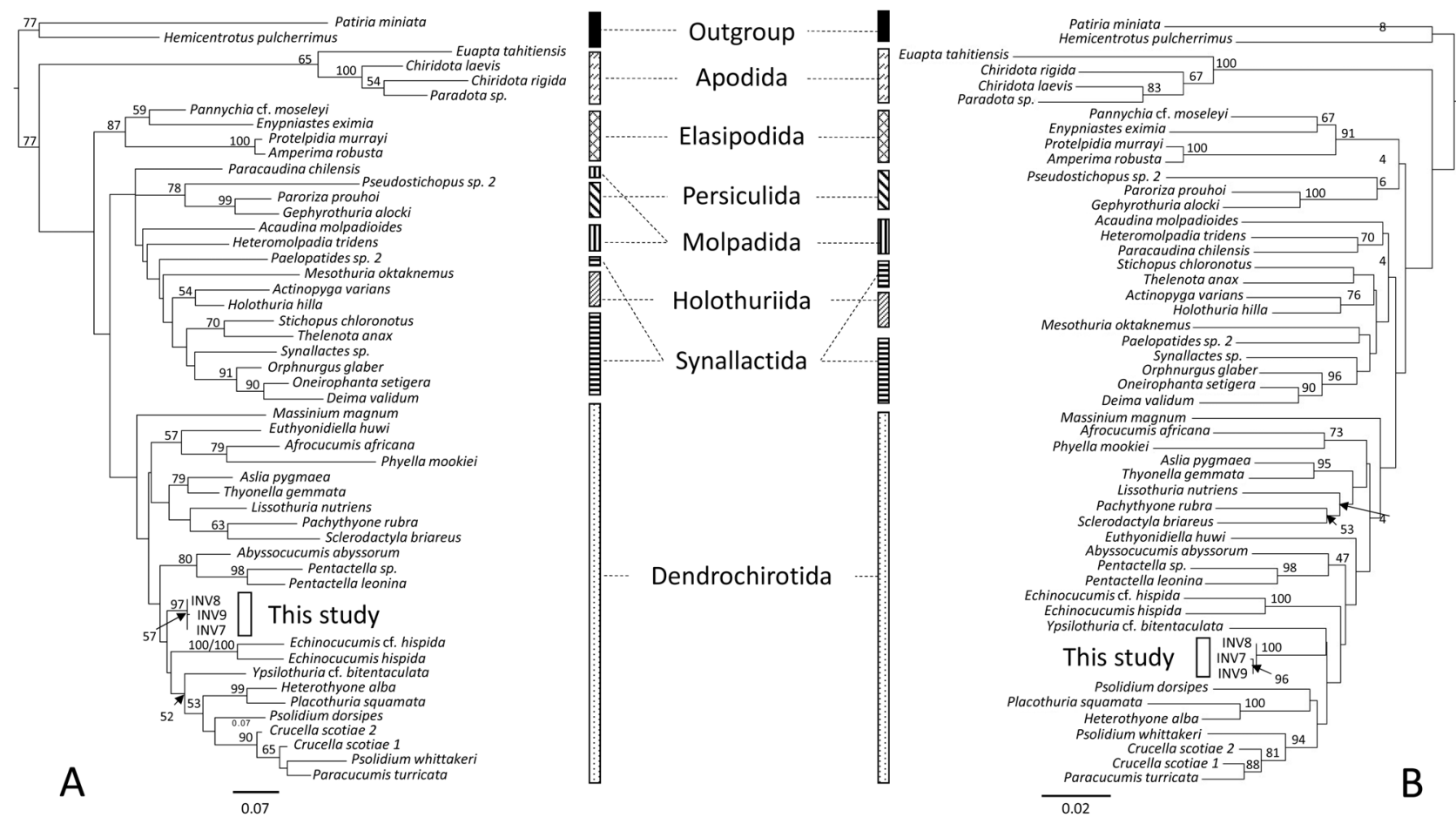

FIGURE 3. Phylogenetic tree (third codon of the COI gene excluded) depicting the position of the specimens in Dendrochirotida. Both of the (A) Maximum Likelihood tree and (B) Neighbor Joining tree show the inclusion of the specimens in Dendrochirotida, and their affinities to the genera Echinocucumis, Ypsilothuria, Heterothyone, Placothuria, Psolidium, Crucella, and Paracucumis, with Afrocucumis and Pentactella as sister clades.

\section{Discussion}

Taxonomic placement of the specimens

Although the most internal and external morphologies of the present species agree well with the characteristics of the family Cucumariidae Ludwig, 1894, the present species have none of the plate, singlefaced $x$-framed cup or x-body (Fig. 2f), or button ossicles, which are usually observed in the body wall of the congeners of Cucumariidae. On the other hand, the body ossicles of the present species have the similar structures to those of some species of the aspidochirotid holothurians, such as the small tables of the genus Labidodemas Selenka, 1867, the dendriformed rods of the genera Thelenota Clark, 1921 and Stichopus Brandt, 1835.

Meanwhile, our molecular phylogenetic tree suggested that the specimens studied here belong to Dendrochirotida, in a clade together with the genera Echinocucumis, Ypsilothuria, Heterothyone, Placothuria, Psolidium, Crucella, and Paracucumis, with Afrocucumis and Pentactella (previous nominal genus of the taxonomic meaning of "Cucumariidae") reported by Miller et al. (2017), as the sister clade to the whole group (Fig. 3). Thus, our molecular study indicates a possibility that the specimens are not cucumariids, but belong to a sister group of Cucumariidae. However, we were unable to place our specimens with certainty in any lower taxonomic group because of the low supports on most nodes. Miller et al. (2017) has suggested that a more exhaustive molecular systematics work is still needed to resolve the interrelationships among the families of dendrochirotids, including to test the monophyly of each family. Therefore future taxonomic and systematics studies will still be needed, not only on our specimens, but also on Dendrochirotida itself.

Although we were unable to pinpoint the specimens' lower taxonomic affinity with certainty, we are confident with the placement of the specimens in Dendrochirotida, because this taxonomic placement has been repetitively consistent, regardless of the phylogenetic method (ML or NJ) used for inference, and the inclusion/exclusion of the third codon position. Moreover, this result is in congruence with the morphological observation. 


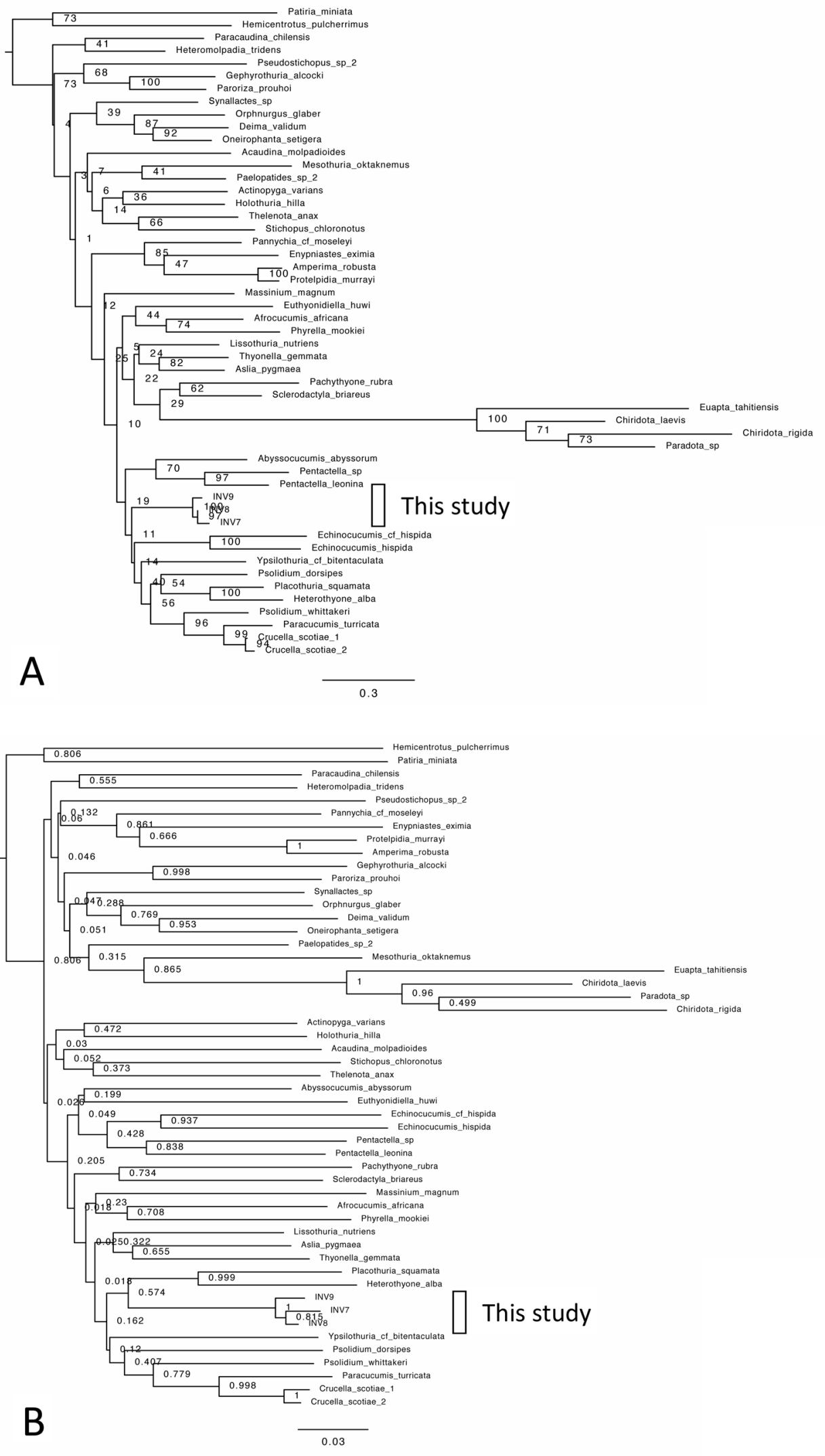

FIGURE 4. Phylogenetic tree (third codon of the COI gene included) depicting the position of the specimens in Dendrochirotida. Both of the (A) Maximum Likelihood tree and (B) Neighbor Joining tree show the inclusion of the specimens in Dendrochirotida, and their affinities to the genera Echinocucumis, Ypsilothuria, Heterothyone, Placothuria, Psolidium, Crucella, and Paracucumis, with Afrocucumis and Pentactella as sister clades. 
Possible origin of double-faced $x$-framed cup ossicle

In dendrochirotid holothurians, some studies show that the fundamental form of ossicle tends to be exist in the peri-oral skin (e.g., O'Loughlin et al. 2012; Yamana et al. 2015). In our present observation, some of the perioral ossicles show a very similar property with the small $x$-framed cup-shaped structures. Furthermore, we found that the structures of the double-faced $x$-framed cup ossicles (Fig. 2a) and normal $x$-framed cups (Fig. $2 \mathrm{f})$ resemble each other in several points: the presence of the central $x$-frame, the marginal rim connectted to the $\mathrm{x}$-frame, and the spinous processes developing on the marginal rim. Judging from these similarity, if a normal $\mathrm{x}$-framed cup ossicle developed four extra-arms on the bottom face, and finally these arms equipped with an extra-rim, it could be considered as a "double-faced x-framed cup ossicle. As we have seen, the new ossicle form "double-faced $x$-framed cup ossicle," could be a derivation pattern of the x-body which sometimes occurs in cucumariids, and could not be rerated to the small table ossicle of some species of the aspidochirotid and dendrochirotid holothurians.

\section{Acknowledgement}

We would like to thank Kazuki Hirota, Kazuma Iwasaki, and other members of the Setiamarga Lab at National Institute of Technology, Wakayama College for their assistance on the molecular works. We also thank the captain and crews of R/V Kaiyo-maru as well as Fisheries Agency of Japan for providing and operating the vessel. We also would like to thank Dr. Munenori Yamashita of Industrial Technology Center of Wakayama Prefecture for providing the equipment of SEM analysis. DHES was partially supported by the Fujiwara Natural History Research Grant (Zoology) 2017, and the National Institute of Technology, Wakayama College Internal Competitive Grant for Research and Education, 2017 and 2018.

\section{References}

Colgan, D.J., McLauchlan, A., Wilson, G.D.F., Livingston, S.P., Edgecombe, G.D., Macaranas, J., Cassis, G. \& Gray, M.R. (1998) Histone H3 and U2 snRNA DNA sequences and arthropod molecular evolution. Australian Journal of Zoology, 46, 419-437. https://doi.org/10.1071/ZO98048

Hoareau, T.B. \& Boissin, E. (2010) Design of phylum-specific hybrid primers for DNA barcoding: addressing the need for efficient COI amplification in the Echinodermata. Molecular Ecology Resources, 10, 960-967. https://doi.org/10.1111/j.1755-0998.2010.02848.x

Katoh, K., Rozewicki, J. \& Yamada, K.D. (2017) MAFFT online service: multiple sequence alignment, interactive sequence choice and visualization. Briefings in Bioinformatics, bbx, 108. https://doi.org/10.1093/bib/bbx108

Kumar, S., Stecher, G. \& Tamura, K. (2016) MEGA7: Molecular Evolutionary Genetics Analysis Version 7.0 for Bigger Datasets. Molecular Biology and Evolution, 33, 1870-1874. https://doi.org/10.1093/molbev/msw054

Maddison, W.P. \& Maddison, D.R. ( 2018) Mesquite: a modular system for evolutionary analysis. Version 3.5. Available from: http://www.mesquiteproject.org (accessed 27 August 2019)

Miller, A.K., Kerr, A.M., Paulay,G., Reich, M., Wilson, N.G., Carvajal, J.I. \& Rouse, G.W. (2017) Molecular Phylogeny of Extant Holothuroidea (Echinodermata), Molecular Phylogenetics and Evolution, 111, 110-131. https://doi.org/10.1016/j.ympev.2017.02.014

O'Loughlin, P.M., Barmos, S. \& VandenSpiegel, D. (2012) The phyllophorid sea cucumbers of southern Australia (Echinodermata: Holothuroidea: Dendorochirotida: Phyllophoridae). Memoirs of Museum Victoria, 69, 269-308. https://doi.org/10.24199/j.mmv.2012.69.05

Silvestro, D. \& Michalak, I. (2012) raxmlGUI: a graphical front-end for RAxML. Organisms Diversity and Evolution, $12,335-337$. https://doi.org/10.1007/s13127-011-0056-0

Yamana, Y., Hirai, A. \& Hirashima, K. (2015) A New Species of Thyone (Echinodermata: Holothuroidea: Dendrochirotida: Phyllophoridae) from Wakayama, Japan. Species Diversity, 20, 141-151. https://doi.org/10.12782/sd.20.2.141

Yamana, Y. \& Kohtsuka, H. (2018) Dendrochirotid holothurians (Echinodermata: Holothuroidea: Dendrochirotida) including four new species, from off Misaki, Japan. Zootaxa, 4455 (3), 429-453.

https://doi.org/10.11646/zootaxa.4455.3.2 